\title{
New Spectrophotometric Methods for the Quantitative Analysis of Fluorometholone in Ophthalmic Suspensions
}

\author{
A.NARENDRA $^{1 *}$, D.DEEPIKA $^{2}$ and M.MATHRUSRI ANNAPURNA ${ }^{3}$ \\ ${ }^{1}$ Micro Advanced Research Centre, Bangalore, Karnataka, India \\ ${ }^{2}$ VijayaInstitue of Pharmaceutical Sciences for women, Vijayawada, A.P, India \\ ${ }^{3}$ GITAM Institute of Pharmacy, GITAM University, Visakhapatnam, A.P., India \\ naren_angirekula@yahoo.com
}

Received 17 December 2012 / Revised 27 January 2013 / Accepted 17 February 2013

\begin{abstract}
Two simple, rapid and sensitive spectrophotometric methods were developed for the determination of Fluorometholone in pharmaceutical formulations in methanol (Method A) and Octane sulfonic acid buffer ( $\mathrm{pH}$ 3.0) (Method B). Beer's law was obeyed over the concentration range 0.1-80 $\mu \mathrm{g} / \mathrm{mL}$ in both methods. The linear regression equations were found to be $\mathrm{y}=0.040 \mathrm{x}+0.005$ and $\mathrm{y}=$ $0.040 \mathrm{x}-0.013$ in Method A and B respectively. The \% RSD was found to be 0.76 and 0.97 in Method A as well as 0.58 and 0.49 in Method B for intra-day and inter-day precision studies. The \% RSD in accuracy studies was also found to be less than 2.0. The proposed methods are simple and suitable for the determination of Fluorometholone in pharmaceutical formulations. No interferences were observed from the excipients in the formulations. The methods were validated according to ICH guidelines.
\end{abstract}

Keywords: Fluorometholone, Eye drops, Validation

\section{Introduction}

Fluorometholone is a corticosteroid, most often used after laser-based refractive surgery. Fluorometholone, chemically $9 \alpha$-fluoro-11b,17 $\alpha$-dihydroxy-6 $\alpha$-methylpregna-1, 4-diene-3,20dione is a corticosteroid employed for its glucocorticoid activity ${ }^{1}$. The drug is formulated as eye drops, in the treatment of allergic and inflammatory conditions of the eye. It has also been used topically in the treatment of various skin disorders ${ }^{2-3}$. However, corticosteroids are thought to act by the induction of phospholipase A2 inhibitory proteins, collectively called lipocortins. It is postulated ${ }^{4}$ that these proteins control the biosynthesis of potent mediators of inflammation such as prostaglandins and leukotrienes by inhibiting the release of their common precursor, arachidonic acid. Arachidonic acid is released from membrane phospholipids by phospholipase A2. Their primary target is the cytosolic glucocorticoid receptor. After binding the receptor the newly formed receptor-ligand complex translocates itself into the cell nucleus, where it binds to many glucocorticoid ${ }^{5}$ response elements in the promoter region of the target genes. The DNA bound receptor then interacts with basic transcription factors, causing the increase in expression of specific target genes. 
A survey of the literature revealed that the methods reported for the determination of fluorometholone include spectrophotometric techniques ${ }^{6-7}$, LC-MS $^{8-10}$ and TLCspectrodensitometric $^{11}$ methods. The authors have developed two simple validated spectrophotometric methods for the determination of Fluorometholone in bulk and pharmaceutical formulations as per ICH guidelines ${ }^{12}$.

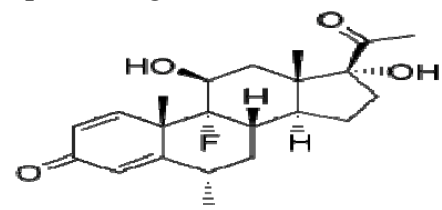

Figure 1. Chemical structure of fluorometholone

\section{Experimental}

A double beam UV-Vis spectrophotometer (UV-1800, Shimadzu, Japan) connected to computer loaded with spectra manager software UV Probe was employed with spectral bandwidth of $1 \mathrm{~nm}$ and wavelength accuracy of $\pm 0.3 \mathrm{~nm}$ with a pair of $10 \mathrm{~mm}$ matched quartz cells. All weights were taken on electronic balance (Denver, Germany). For scanning, the wavelength range selected was from $400 \mathrm{~nm}$ to $200 \mathrm{~nm}$ with medium scanning speed. All experiments were performed at room temperature $(25 \pm 1)^{\circ} \mathrm{C}$.

\section{Reagents and chemicals}

Fluorometholone standard (purity $\geq 98.0 \%$ ) was obtained from Eisai Pharmaceuticals (India). Fluorometholone is available commercially with brand names FLAREX and FLUMETHOLON (containing $0.1 \%$ of the drug content) respectively and were procured from the local market.

\section{Preparation of stock and sample solution}

The standard solution of fluorometholone was prepared by dissolving accurately about 25 $\mathrm{mg}$ of the Fluorometholone with methanol in a $25 \mathrm{~mL}$ volumetric flask.

\section{Preparation of 0.02M Octane1- sulfonic acid buffer ( $p H$ 3.0)}

$4.35 \mathrm{~g}$ of Octane 1- sulfonic acid was dissolved in $1000 \mathrm{~mL}$ of water and $\mathrm{pH}$ was adjusted to 3.0 with $o$-phosphoric acid. The stock solution was further diluted with methanol and Octane sulfonic acid buffer ( $\mathrm{pH} 3.0)$ for method A and method B $(0.1-80 \mu \mathrm{g} / \mathrm{mL})$ to obtain required sample solutions.

\section{Procedure}

\section{Method A}

The drug solution was scanned (200-400 nm) against reagent blank (methanol) and the absorption spectrum (Figure 2$)$ was recorded. The absorption maximum $\left(\lambda_{\max }\right)$ was observed at $240 \mathrm{~nm}$. A series of solutions $(0.1-80 \mu \mathrm{g} / \mathrm{mL})$ were prepared and the absorbance of these solutions was recorded at that $\lambda_{\max }$.

A graph was plotted by taking the concentration of the solutions on the $\mathrm{x}$-axis and the corresponding absorbance values on the y-axis (Figure 3).

\section{Method B}

The drug solution was scanned $(200-400 \mathrm{~nm})$ against reagent blank (Octane 1-sulfonic acid buffer $\mathrm{pH}$ 3.0) and the absorption spectrum was recorded (Figure 4). A series of solutions (0.1$80 \mu \mathrm{g} / \mathrm{mL}$ ) were prepared and the absorbance of these solutions was recorded at that $\lambda_{\max }$. 


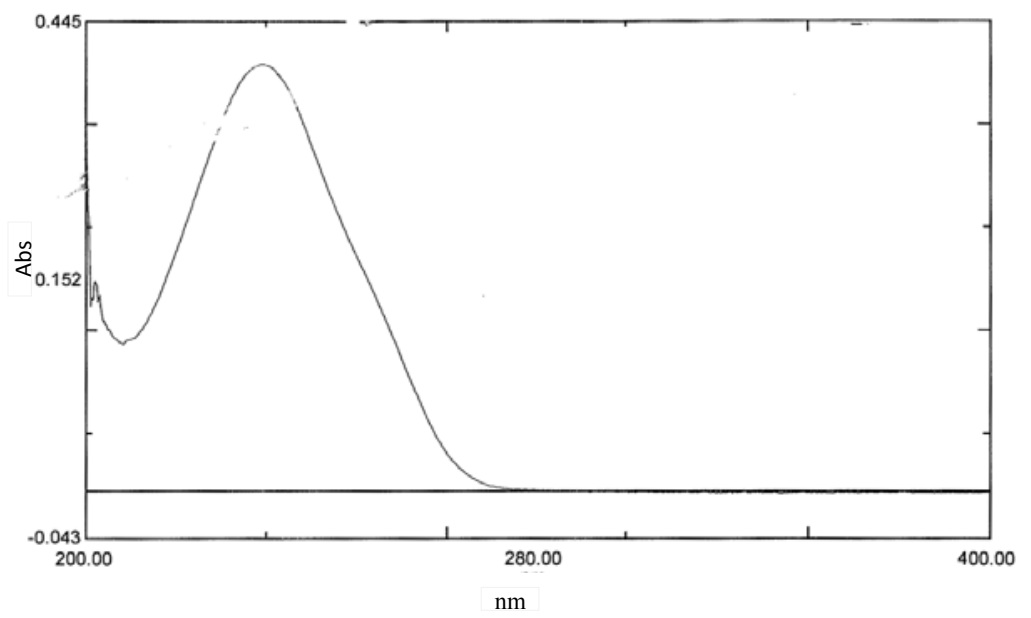

Figure 2.Absorption spectrum of fluorometholone $(10 \mu \mathrm{g} / \mathrm{mL})$ (Method A)

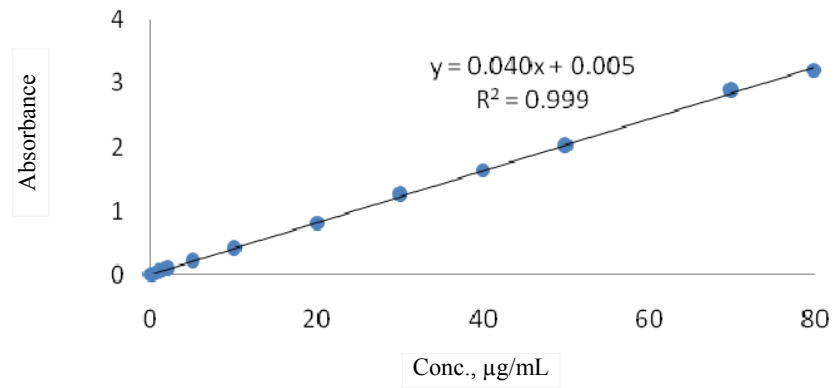

Figure 3.Calibration curve of fluorometholone (Method A)

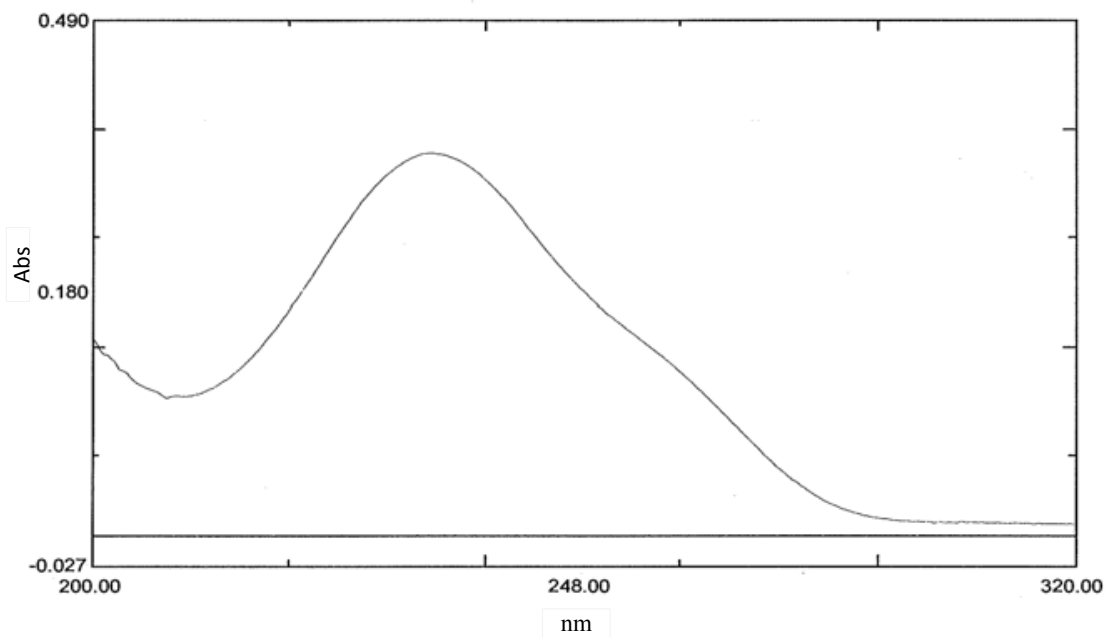

Figure 4. Absorption spectrum of fluorometholone $(10 \mu \mathrm{g} / \mathrm{mL})$ (Method B)

A graph was plotted by taking the concentration of the solutions on the $\mathrm{x}$-axis and the corresponding absorbance values on the y-axis (Figure 5). 




Figure 5.Calibration curve of fluorometholone (Method B)

\section{Assay of commercial formulations}

Fluorometholone is available in the local market with brand names $\operatorname{FLAREX}(0.1 \%)$ and flumetholon $(0.1 \%)$ were purchased. Five containers were collected each marketed brand, and equivalent to $5.0 \mathrm{~g}$ of the drug was weighed, extracted with methanol separately, sonicated and make up to volume in two different $50 \mathrm{~mL}$ volumetric flasks $(20 \mu \mathrm{g} / \mathrm{mL})$ and filtered. Further dilutions were made from this stock solution with methanol and Octane 1-sulfonic acid buffer for method $\mathrm{A}$ and $\mathrm{B}$ and analyzed according to the recommended procedure.

\section{Precision and accuracy}

The precision study was done by recording the absorbance of six replicates $(20 \mu \mathrm{g} / \mathrm{mL})$ for method A and B and the \% RSD was calculated. Accuracy was evaluated by the recovery studies by the addition of $80 \%, 100 \%$ and $120 \%$ of pure drug solution to the pre-analysed formulation solution. For the present study FML drug solution extracted from the formulation was taken and $80 \%, 100 \%$ and $120 \%$ of pure drug solution (i.e. 8,10 and 12 $\mu \mathrm{g} / \mathrm{mL}$ ) were added to the $10 \mu \mathrm{g} / \mathrm{mL}$ and the $\%$ RSD was calculated.

\section{Results and Discussion}

The optical characteristics of the proposed methods were shown in Table 1. Beer's law was obeyed in the concentration range of $0.1-80 \mu \mathrm{g} / \mathrm{mL}$ and $0.1-80 \mu \mathrm{g} / \mathrm{mL}$ for the methods $A$ and $\mathrm{B}$ respectively. The linear regression equations were found to be $\mathrm{Y}=0.040 \mathrm{x}+0.005$ and $\mathrm{Y}$ $=0.040 \mathrm{x}-0.013$ for method A and B respectively with correlation coefficient 0.9998 and 0.9996 respectively for both methods.

The $\%$ RSD values for precision and accuracy studies of both the methods were found to be $(\mathrm{RSD}<2 \%)$ indicating that the methods are more precise and accurate. The percentage recovery was found to be 99.65-99.12 and 99.59-100.40 for method A and B respectively (Table 2). The proposed methods can be applied successfully for the determination of Fluorometholone in pharmaceutical formulations.

Table 1. Optical characteristics of fluorometholone

\begin{tabular}{lcc}
\hline \multicolumn{1}{c}{ Parameters } & Method A & Method B \\
\hline Beer-Lambert's range, $\mu \mathrm{g} / \mathrm{mL}$ & $0.1-80$ & $0.1-80$ \\
$\lambda$ max/ wave length range, $\mathrm{nm}$ & 240 & 240 \\
Molar absorptivity, $\mathrm{L} / \mathrm{mol}^{\prime} \mathrm{cm}$ & $1.5209 \times 10^{4}$ & $1.3590 \times 10^{4}$ \\
Sandell's sensitivity $(\mu \mathrm{g} \mathrm{cm} / 0.001 \mathrm{Abs})$ & 0.024752 & 0.02770 \\
Regression equation Y & & \\
Slope & 0.040 & 0.013 \\
Intercept & 0.005 & 0.013 \\
Correlation coefficient & 0.9998 & 0.9996 \\
\hline
\end{tabular}


Table 2. Analysis of fluorometholone commercial formulation

\begin{tabular}{|c|c|c|c|c|c|c|c|}
\hline \multirow{3}{*}{ Brand } & \multirow{3}{*}{$\begin{array}{c}\text { Labelled } \\
\text { Amount, } \\
\%\end{array}$} & \multirow{2}{*}{\multicolumn{2}{|c|}{$\begin{array}{c}\text { Amount } \\
\text { Obtained, mg } \\
\text { Method }\end{array}$}} & \multicolumn{2}{|c|}{$\%$ Recovery } & \multicolumn{2}{|c|}{$\%$ RSD } \\
\hline & & & & & & & ood \\
\hline & & A & $\mathrm{B}$ & $\mathrm{A}$ & $\mathrm{B}$ & A & $\mathrm{B}$ \\
\hline FLAREX & 0.1 & 0.0996 & 0.0995 & 99.65 & 99.59 & 0.46 & 0.58 \\
\hline FLUMETHOLON & 0.1 & 0.0991 & 0.100 & 99.12 & 100.95 & 0.68 & 0.79 \\
\hline
\end{tabular}

\section{Conclusion}

The present methods can be employed for the determination of fluorometholone in pharmaceutical formulations successfully and there is no interference of excipients during the study.

\section{Acknowledgement}

The authors are grateful of M/S Pharmatrain Laboratories, India for providing research facilities and also to Eisai Pharmaceuticals (India) for providing the gift samples of the drug.

\section{References}

1. The Merck Index, An Encyclopedia Of Chemical, Drug's and Biologicals, Maryadele J O Neil.Eds, $14^{\text {th }}$ Edition, Published by Merck Research Lab, Division of Merck and Co. Inc., Whitehouse Station, NJ: 2006., 4175, 714.

2. Sweetman S C, Martindale: The Complete Drug Reference, Pharmaceutical Press, London, 2005.

3. Samudre S S, Lattanzio F A Jr, Williams P B and Sheppard J D Jr, J Ocul Pharmacol Ther., 2004, 20(6), 533-547.

4. Grossman R, Yehuda R, Golier J, McEwen B, Harvey P and Maria N S, Ann N Y Acad Sci., 2006, 1071, 410-421.

5. Hammer F and Stewart P M, Best Pract Res Clin Endocrinol Metab., 2006, 20(3), 337-353.

6. Altuntas T G, Korkmaz F and Nebioglu D, Pharmazie., 2000, 55(1), 49-52.

7. Vladimirov S, Cudina O, Agbaba D and Zivanov-Stakic D, Anal Lett., 1996, 29(6), 921-927.

8. Korpi-Steiner N L, Netzel B C, Seegmiller J C, Hagan J B and Singh R J, Steroids, 2010, 75(1), 77-82; DOI:10.1016/j.steroids.2009.10.009.

9. Croesa K, Goeyensa L, Baeyens W, Loco J V and Impens S, J Chromatogr B, 2009, 877(7), 635-644; DOI:10.1016/j.jchromb.2009.01.028.

10. Keeffe M J O, Martin S and Regan Y, Anal Chim Acta, 2003, 483(1-2), 341-350; DOI:10.1016/S0003-2670(03)00059-X.

11. Sarah S Saleha, Hayam M Lotfy, Nagiba Y Hassan, Samia M Elgizawy, Saudi Pharma J., 2013, 21(4), 411-421; http://dx.doi.org/10.1016/j.jsps.2012.11.001, Available online 17 November 2012.

12. International Conference on Harmonization (ICH), Q2B: Validation of Analytical Procedures: Methodology, 62, US FDA, Federal Register, 2005. 